\title{
RADIOCARBON IN SEAWATER AND ORGANISMS FROM THE PACIFIC COAST OF BAJA CALIFORNIA
}

\author{
ELLEN R. M. DRUFFEL
}

Woods Hole Oceanographic Institution, Woods Hole, Massachusetts 02543 USA

and

PETER M. WILLIAMS

Scripps Institution of Oceanography, La Jolla, California 92093 USA

\begin{abstract}
Radiocarbon was measured in dissolved inorganic carbon (DIC) and living organisms collected off the west coast of Baja California in October 1980. Samples from three locations were examined. $\Delta^{14} \mathrm{C}$ of DIC at the southernmost station was higher than those further north, which reflects reduced upwelling in the southern region. Crabs and anchovies had $\Delta^{14} \mathrm{C}$ values significantly lower than surface DIC $\Delta^{14} \mathrm{C}$, indicating the incorporation of 'older', sediment-derived carbon sources from their diets. Comparisons are made between our DIC $\Delta^{14} \mathrm{C}$ measurements and those obtained during other cruises and at a coastal site, from 1959 through 1987. Two distinct time histories of DIC $\triangle^{14} \mathrm{C}$ are apparent for the post-bomb period: 1) a lower $\Delta^{14} \mathrm{C}$ curve for sites close to the coast influenced by enhanced coastal upwelling; and 2) a higher $\Delta^{14} \mathrm{C}$ curve for sites further offshore within the California Current.
\end{abstract}

\section{INTRODUCTION}

Bomb radiocarbon was produced in the stratosphere during the late 1950s and early 1960s. As a result of its production, atmospheric ${ }^{14} \mathrm{CO}_{2}$ levels increased by nearly two times in the northern hemisphere (Nydal \& Løvseth 1983). By exchange of $\mathrm{CO}_{2}$ between atmosphere and surface ocean waters, bomb radiocarbon has slowly infiltrated the upper ocean. Time histories of radiocarbon in the surface ocean during the post-bomb period have allowed us to examine various short-term processes that control carbon exchange in this layer: 1) gas exchange with the atmosphere; 2) vertical mixing with subsurface waters that generally contain lower radiocarbon activities; and 3) lateral mixing with water masses of distinct ${ }^{14} \mathrm{C}$ signatures.

We report $\Delta^{14} \mathrm{C}$ results for the coastal region off Baja California. When compared with similar measurements from the coastal and offshore locations for the entire post-bomb period, a pattern emerges that reveals two distinct $\Delta^{14} \mathrm{C}$ trends. The area within $c a .150 \mathrm{~km}$ of the coast contains significantly lower levels of bomb ${ }^{14} \mathrm{C}$, due to dilution by 'old', upwelling waters. Locations offshore have consistently higher $\Delta^{14} \mathrm{C}$ values than coastal regions examined during the same calendar year, which is expected, due to reduced upwelling in the California Current.

\section{MATERIAL AND METHODS}

Samples reported here were collected during a surface film cruise (SF-2) on the $R / V$ New Horizon in October 1980. For a description of the chemical and biological characteristics of the sea-surface films and near-surface waters studied in this region, the reader is referred to Williams et al. (1986).

Surface seawater samples $(190 \mathrm{~L}$ ) were collected from $2 \mathrm{~m}$ depth, using a Jabsco pump mounted on the main deck. A subsurface water sample was collected from $200 \mathrm{~m}$ at Site 2 by making 6 casts of a $30-\mathrm{L}$ Niskin bottle. Each water sample was stored in a 210-L polyethylene-lined steel drum, to which $1 \mathrm{~g}$ of mercuric chloride had been added to poison biological activity. To avoid the possibility of contamination by ${ }^{14} \mathrm{C}$-labeled compounds that were being used aboard ship, the drums were returned to the La Jolla Radiocarbon Laboratory for extraction. 
DIC was stripped from each water sample using standard methods (Linick 1980). One liter of concentrated sulfuric acid was added, and the drum was heated to $50^{\circ} \mathrm{C}$. A small volume of air $(10-20 \mathrm{Ls})$ above the seawater solution was recirculated, using a peristaltic pump, and the air was bubbled through a $1-\mathrm{L}$ solution of $15 \mathrm{~N} \mathrm{NH}_{4} \mathrm{OH}$ and $1 \mathrm{M} \mathrm{SrCl}_{2}$ for four hours. Most of the ammonia was decanted, and then the solution was heated under vacuum to remove residual ammonia, leaving a dried precipitate of strontium carbonate. Acid digestion was performed with $2 \mathrm{~N} \mathrm{HCl}$, and the evolved $\mathrm{CO}_{2}$ was collected. $\mathrm{CO}_{2}$ was converted to acetylene gas via a lithium carbide intermediate (Linick 1975).

Three biological samples were collected from 0-1 m depth in Thurloe Bay on the night of 8 October 1980. Collections were made with a hand net from the $R / V$ New Horizon's main deck. Samples were frozen and brought back to the laboratory for radiocarbon analysis. Inorganic carbon was removed from each sample initially using $2 \mathrm{~N} \mathrm{HCl}$. The samples were dried and burned in a stream of medical-grade oxygen at $600^{\circ} \mathrm{C}$. The resultant $\mathrm{CO}_{2}$ was converted to $\mathrm{C}_{2} \mathrm{H}_{2}$ via $\mathrm{Li}_{2} \mathrm{C}_{2}$. The smallest sample (LJ-5459 Crabs) was counted as $\mathrm{CO}_{2}$.

Samples were counted for two, 2-day periods in quartz $(2.2$ and $2.5 \mathrm{~L})$ or stainless steel $(0.4$ and $1.0 \mathrm{~L}$ ) gas proportional beta counters and at $900 \mathrm{~mm} \mathrm{Hg}$ and $25^{\circ} \mathrm{C}$. The crabs (LJ-5459) sample was counted for two 6-day periods in a 0.20 - $\mathrm{L}$ copper counter.

Samples were measured relative to $95 \%$ of NBS Oxalic Acid I activity, corrected to a $\delta^{13} \mathrm{C}$ of $-19.0 \%$ (PDB). Sample activity was corrected to a $\delta^{13} \mathrm{C}$ of $-25.0 \%$. Results are reported in the standard $\triangle^{14} \mathrm{C}$ notation (in per mil, Stuiver \& Polach 1977). Uncertainties given are one-sigma deviation errors based on statistics of sample, standard and background activities.

\section{RESULTS}

The $\Delta^{14} \mathrm{C}$ results of DIC and biological organisms collected on the SF-2 cruise are reported in Table 1. Figure 1 shows sampling locations. The first DIC (Site 1) sample had a surface $\Delta^{14} \mathrm{C}$ value of $+109 \pm 8 \%$, and was located just south of the U.S./Mexico border, $c a .18 \mathrm{~km}$ offshore. Site 2 was located $c a .140 \mathrm{~km}$ offshore of Baja. The surface DIC sample was $+113 \pm 4 \%$ in $\Delta^{14} \mathrm{C}$, and the sample at $200 \mathrm{~m}$ depth was $-5 \pm 4 \%$. Site 3 was $4 \mathrm{~km}$ outside of Thurloe Bay $(5 \mathrm{~km}$ from shore), and the surface DIC $\Delta^{14} \mathrm{C}$ value was $+133 \pm 4 \%$.

The $\Delta^{14} \mathrm{C}$ results from three samples of organisms collected from the surface waters of Thurloe Bay were all similar within the reported error. A large anchovy measured $+72 \pm 7 \%$, numerous small anchovies $(-10 \mathrm{~cm}$ long) were $+79 \pm 7 \%$, and numerous pelagic crabs (Pleuroncodes planipes, $1-2$ $\mathrm{cm}$ long) were $+58 \pm 17 \%$.

\section{DisCUSSION}

Waters off the California and Baja coasts are influenced by marked upwelling in spring and early summer, induced by northerly winds. By October, upwelling all but ceases (Sverdrup, Johnson \& Fleming 1942). As a result, there is little seasonal variation in temperature in the California coastal region.

Seawater $\Delta^{14} \mathrm{C}$ results appear to increase as one goes further south along the Baja coast (Table 1). To the south are waters of lower salinity and higher temperature. Density profiles indicate less communication between surface and subsurface waters in the southern region than in waters to the north. Thus, we expect to find higher $\Delta^{14} \mathrm{C}$ values in the surface waters to the south. 
TABLE 1. Radiocarbon Measurements for Samples Collected on SF-2 Cruise (October 1980)

\begin{tabular}{|c|c|c|c|c|c|c|c|}
\hline C Pool & LJ-\# & Site \# & $\begin{array}{c}\text { Collection } \\
\text { date }\end{array}$ & Location & $\begin{array}{l}\text { Depth } \\
(\mathrm{m})\end{array}$ & $\begin{array}{l}\Delta^{14} \mathrm{C} \\
(\% 0)\end{array}$ & $\begin{array}{l}\delta^{13} \mathrm{C} \\
(\% 0) \\
\end{array}$ \\
\hline DIC & 5258 & 1 & 4 Oct 1980 & $\begin{array}{l}31^{\circ} 59.8^{\prime} \mathrm{N} \\
117^{\circ} 12.0^{\prime} \mathrm{W}\end{array}$ & 2 & $+109 \pm 8$ & +0.3 \\
\hline DIC & 5260 & 2 & 5 Oct 1980 & $\begin{array}{l}28^{\circ} 38.5^{\prime} \mathrm{N} \\
117^{\circ} 04.3^{\prime} \mathrm{W}\end{array}$ & 2 & $+113 \pm 4$ & +3.4 \\
\hline DIC & 5261 & 2 & 5 Oct 1980 & $\begin{array}{l}28^{\circ} 37.8^{\prime} \mathrm{N} \\
117^{\circ} 04.3^{\prime} \mathrm{W}\end{array}$ & 200 & $-5 \pm 4$ & -1.2 \\
\hline DIC & 5259 & 3 & 10 Oct 1980 & $\begin{array}{l}27^{\circ} 33.0^{\prime} \mathrm{N} \\
114^{\circ} 52.3^{\prime} \mathrm{W}\end{array}$ & 2 & $+133 \pm 4$ & -1.9 \\
\hline $\begin{array}{l}\text { Anchovy } \\
\text { (large) }\end{array}$ & 5457 & 3 & 8 Oct 1980 & $\begin{array}{l}27^{\circ} 37.3^{\prime} \mathrm{N} \\
114^{\circ} 50.1^{\prime} \mathrm{W}\end{array}$ & $0-1$ & $+72 \pm 7$ & -18.3 \\
\hline $\begin{array}{l}\text { Anchovies } \\
(10 \mathrm{~cm})\end{array}$ & 5458 & 3 & 8 Oct 1980 & $\begin{array}{l}27^{\circ} 37.3^{\prime} \mathrm{N} \\
114^{\circ} 50.1^{\prime} \mathrm{W}\end{array}$ & $0-1$ & $+79 \pm 7$ & -18.3 \\
\hline $\begin{array}{l}\text { Crabs } \\
\text { Pleuroncodes } \\
\text { planipes } \\
(1-2 \mathrm{~cm})\end{array}$ & 5459 & 3 & 8 Oct 1980 & $\begin{array}{l}27^{\circ} 37.3^{\prime} \mathrm{N} \\
114^{\circ} 50.1^{\prime} \mathrm{W}\end{array}$ & $0-1$ & $+58 \pm 17$ & -19.5 \\
\hline
\end{tabular}

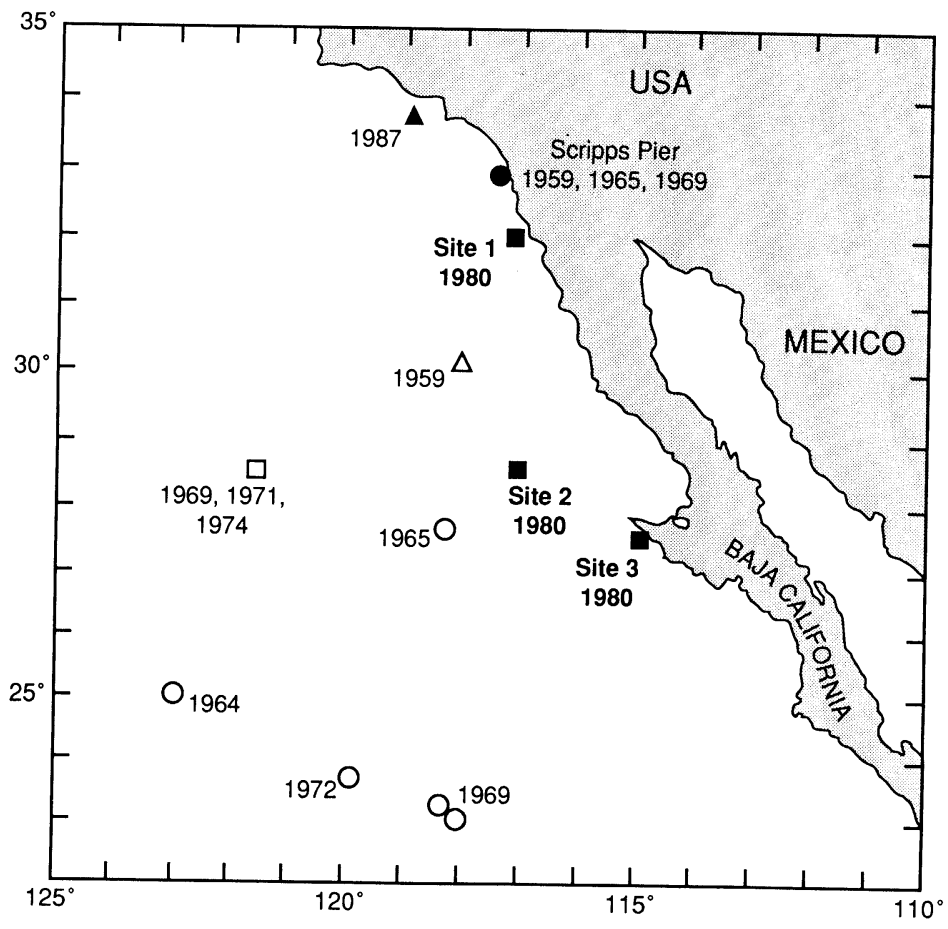

Fig. 1. Map of sampling locations aboard the R/V New Horizon on SF2 cruise ( $\bullet$ ). Also shown are locations and year(s) of collection for samples reported by other investigators, plotted in Figures 2 and 3. 


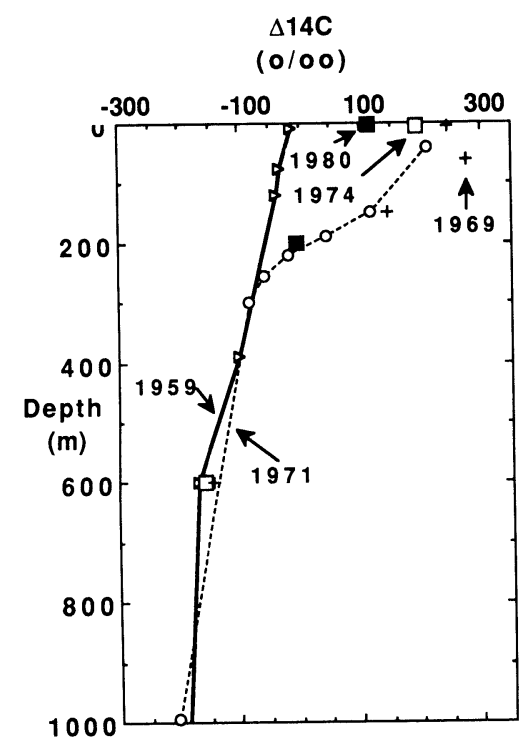

Fig. 2. Depth profiles of $\Delta^{14} \mathrm{C}$ from our Site 2 in $1980(\boldsymbol{m})$ and from the GEOSECS test $(1969,+)$, GOGO I $(1971,0)$ and $\operatorname{GEOSECS~}(1974, \square)$ stations $\left(28.5^{\circ} \mathrm{N}, 121.5^{\circ} \mathrm{W}\right) 450 \mathrm{~km}$ offshore of Baja California (Östlund \& Niskin 1970; Roether 1974; Östlund \& Stuiver 1980). A depth profile taken in $1959(\triangleright)$ reported by Bien, Rakestraw \& Suess (1965), from $30.0^{\circ} \mathrm{N}, 118.0^{\circ} \mathrm{W}$, is shown for comparison.

Higher $\Delta^{14} \mathrm{C}$ values were reported for samples collected from a location $450 \mathrm{~km}$ offshore from Baja. This station, at $28^{\circ} 30^{\prime} \mathrm{N}, 121^{\circ} 44^{\prime} \mathrm{W}$, was occupied as a GEOSECS test site in September 1969 (Östlund \& Niskin 1970). It was reoccupied as GOGO I site in November 1971 (Roether 1974), and during GEOSECS again as Stn. 347 in June 1974 (Östlund \& Stuiver 1980). $\Delta^{14} \mathrm{C}$ depth profiles from these studies and from Site 2 are shown in Figure 2. A profile taken in 1959 reported by Bien, Rakestraw \& Suess (1965) for a station $160 \mathrm{~km}$ offshore of Bahia Colnet are plotted for comparison in Figure 2. Our two $\Delta^{14} \mathrm{C}$ values from $2 \mathrm{~m}$ and $200 \mathrm{~m}$ near the coast of Baja were significantly lower in $\Delta^{14} \mathrm{C}$ than those observed offshore at the GEOSECS/GOGO site, despite the fact that our samples were taken several years later. Dilution of nearshore water due to upwelling is the likely reason for these low coastal $\Delta^{14} \mathrm{C}$ values near the coast. Also, horizontal advection of bomb radiocarbon from the north to the offshore GEOSECS site via the California Current cause overall higher $\Delta^{14} \mathrm{C}$ values (Broecker \& Peng 1980).

Time histories of $\Delta^{14} \mathrm{C}$ in surface waters off the southern California/Baja coast reveal overall lower values in nearshore regions. In Figure $3, \Delta^{14} \mathrm{C}$ DIC values for nearshore (within $150 \mathrm{~km}$ ) and offshore $\left(150-500 \mathrm{~km}\right.$ ) locations are plotted versus the year of collection. $\triangle^{14} \mathrm{C}$ DIC values rose more quickly at the offshore locations, owing to the reduced upwelling that occurs further from shore. This offshore $\Delta^{14} \mathrm{C}$ trend resembles that observed in the mid-gyre region of the North Pacific Ocean, as reconstructed by annual coral bands (Druffel 1987) (Fig. 3). The time history' of $\Delta^{14} \mathrm{C}$ from Galapagos corals (Druffel 1981) is also shown in Figure 3 as an example of a record influenced by intense upwelling. From the bomb ${ }^{14} \mathrm{C}$ records, it is apparent that upwelling near the Baja coast is not as intense as it is near the Galapagos Islands in the eastern equatorial Pacific, though it is significant enough to support increased levels of nutrients and primary production.

Low $\Delta^{14} \mathrm{C}$ values found for the three biological samples are likely due to feeding on sediment-derived carbon and on organisms that contain low ${ }^{14} \mathrm{C}$ activity carbon. Pearcy and Stuiver (1983) and Williams, Druffel and Smith (1987) found reduced ${ }^{14} \mathrm{C}$ activities for meso- and abyssopelagic organisms in the North Pacific, owing at least in part to incorporation of 'old' carbon from mid-water regions. 


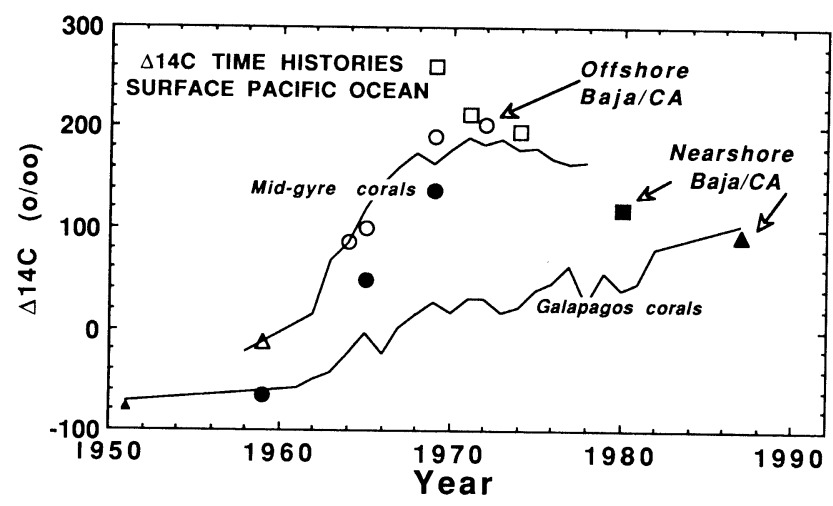

Fig. 3. Time histories of $\Delta^{14} \mathrm{C}$ from DIC and shells from $>150 \mathrm{~km}$ offshore of Baja California $(\Delta-$ Bien, Rakestraw \& Suess 1965; ○ - Linick 1975; $\square$ - Östlund \& Niskin 1970; Roether 1974; Östlund \& Stuiver 1980) and the coastal region $<150 \mathrm{~km}$ from shore (- - this study; $\Delta$ - Berger, Taylor \& Libby 1966, Robinson \& Thompson, 1981; - - Scripps pier, Linick 1975; $\mathbf{\Delta}$ - Williams et al. 1991). For comparison, $\Delta^{14} \mathrm{C}$ records from annually banded corals from the Galapagos Islands $\left(1^{\circ} \mathrm{S}, 90^{\circ} \mathrm{W}\right)$ and French Frigate Shoals $\left(24^{\circ} \mathrm{N}, 166^{\circ} \mathrm{W}\right)$ are also plotted (Druffel 1981, 1987).

The $\Delta^{14} \mathrm{C}$ results reported here add to the data base that documents the input of bomb-produced isotopes to the oceans. The continued examination of these quantities allow us to view oceanic properties, such as circulation, on much shorter time scales than would have been allowed, if these spike tracers had not been introduced. It is the silver lining on the cloud of nuclear weapons testing.

\section{ACKNOWLEDGMENTS}

Our thanks go to Sheila Griffin, who assisted in the shore-based radiocarbon analyses. We appreciate the help of the crew of the $R / V$ New Horizon. This work was supported by National Science Foundation Grant Nos. OCE-7917653 and OCE-8111954. WHOI Contribution No. 7845.

\section{REFERENCES}

Berger, R., Taylor, R. E. and Libby, W. F. 1966 Radiocarbon content of marine shells from the California and Mexican west coast. Science 153: 864-866.

Bien, G. S., Rakestraw, N. W. and Suess, H. E. 1965 Radiocarbon in the Pacific and Indian Oceans and its relation to deep water movements. Limnology and Oceanography 10: R25-R37.

Broecker, W. S. and Peng, T.-H. 1980 The distribution of bomb-produced tritium and radiocarbon at GEOSECS Station 347 in the eastern North Pacific. Earth and Planetary Science Letters 49: 453-462.

Druffel, E. M. 1981 Radiocarbon in annual coral rings from the eastern tropical Pacific Ocean. Geophysical Research Letters 8: 58-61.

1987 Bomb radiocarbon in the Pacific: Annual and seasonal timescale variations. Journal of Marine Research 45: 667-698.

Linick, T. W. (ms.) 1975 Uptake of bomb-produced carbon- 14 by the Pacific Ocean. Ph.D. dissertation,
University of California at San Diego: $255 \mathrm{p}$.

1980 Bomb-produced carbon-14 in the surface water of the Pacific Ocean. In Stuiver, M. and Kra, R. S., eds., Proceedings of the 10 th International ${ }^{14} \mathrm{C}$ Conference. Radiocarbon 22(3):599-606.

Nydal, R. and Løvseth, K. 1983 Tracing bomb ${ }^{14} \mathrm{C}$ in the atmosphere 1962-1980. Journal of Geophysical Research 88: 3621-3642.

Östlund, H. G. and Niskin, S. 1970 Radiocarbon profile in the North Pacific 1969 Geosecs Intercalibration Station. Journal of Geophysical Research 75: 7667.

Östlund, H. G. and Stuiver, M. 1980 GEOSECS Pacific Radiocarbon. Radiocarbon 22(1): 25-53.

Pearcy, W. G. and Stuiver, M. 1983 Vertical transport of carbon-14 into deep-sea food webs. Deep-Sea Research 30: 427-440.

Roether, W. 1974 The tritium and carbon-14 profiles at the Geosecs I (1969) and GOGO I (1971) North Pacific Stations. Earth and Planetary Science Letters 
23: $108-115$.

Stuiver, M. and Polach, H. A. 1977 Discussion: Reporting of ${ }^{14} \mathrm{C}$ data. Radiocarbon 19(3): 355-363.

Robinson, S. W. and Thompson, G. 1981 Radiocarbon corrections for marine shell dates with application to southern Pacific Northwest coast prehistory. Syesis 14: 45-57.

Sverdrup, H. U., Johnson, M. W. and Fleming, R. H. 1942 The Oceans: Their Physics, Chemistry and General Biology. Englewood Cliffs, New Jersey, Prentice-Hall, Inc.: 131-132, 724-727.

Williams, P. M., Carlucci, A. F., Henrichs, S. M., Van Vleet, E. S., Horrigan, S. F., Reid, F. M. H. and
Robertson, K. J. 1986 Chemical and microbiological studies of sea-surface films in the southern Gulf of California and off the west coast of Baja California. Marine Chemistry 19: 17-98.

Williams, P. M., Druffel, E. R. M. and Smith, K. L. 1987 Dietary carbon sources for deep-sea organisms as inferred from their organic radiocarbon activities. Deep-Sea Research 34(2): 253-266.

Williams, P. M., Robertson, K. J., Soutar, A., Griffin, S. M. and Druffel, E. R. M. 1991 Isotopic signatures $\left({ }^{14} \mathrm{C},{ }^{13} \mathrm{C},{ }^{14} \mathrm{~N}\right)$ as tracers of sources and cycling of soluble and particulate organic matter in the Santa Monica Basin. Progress in Oceanography, in press. 